Article

\title{
Disruptive Technologies for Improving Water Security in Large River Basins
}

\author{
Nagaraja Rao Harshadeep * and William Young \\ World Bank, 1818 H Street, Washington, DC 20433, USA; w.young@worldbank.org \\ * Correspondence: harsh@worldbank.org
}

Received: 11 May 2020; Accepted: 24 September 2020; Published: 6 October 2020

check for updates

\begin{abstract}
Large river basins present significant challenges for water resource planning and management. They typically traverse a wide range of hydroclimatic regimes, are characterized by complex and variable hydrology, and span multiple jurisdictions with diverse water demands and values. They are often data-poor and in many developing economies are characterized by weak water governance. Rapid global change is seeing significant changes to the pressures on the water resources of large basins, exacerbating the challenge of sustainable water management. Diverse technologies have long supported water resource planning and development, from data collection, analytics, simulation, to decision-making, and real-time operations. In the last two decades however, a rapid increase in the range, capability, and accessibility of new technologies, coupled with large reductions in cost, mean there are increasing opportunities for emerging technologies to significantly "disrupt" traditional approaches to water resources management. In this paper, we consider the application of 'disruptive technologies' in water resources management in large river basins, through a lens of improving water security. We discuss the role of different actors and institutions for water management considering a range of emerging disruptive technologies. We consider the risks and benefits associated with the use of these technologies and discuss the barriers to their widespread adoption. We obverse a positive trend away from the reliance solely on centralized government institutions and traditional modeling for the collection and analysis of data, towards a more open and dynamic 'data and knowledge ecosystem' that draws upon data services at different levels (global to local) to support water planning and operations. We expect that technological advances and cost reductions will accelerate, fueling increased incremental adoption of new technologies in water resources planning and management. Large-basin analytics could become virtually free for users with global, regional, and national development agencies absorbing the costs of development and any subscription services for end users (e.g., irrigators) to help improve water management at user level and improve economic productivity. Collectively, these changes can help to 'democratize' water management through improved access to data and information. However, disruptive technologies can also be deployed in top-down or centralized processes, and so their use is sometimes contested or misunderstood. Increased attention therefore needs to be given to ensuring equity in technology access, and to strengthening the governance context for technology deployment. Widespread adoption of disruptive technologies will require adjustments to how water professionals are trained, increased adaptiveness in water resources planning and operations, and careful consideration of privacy and cybersecurity issues.
\end{abstract}

Keywords: disruptive technology; river basins; large basins; water security; water resources management; water governance; water data; information technology; analytics 


\section{Introduction}

Water management is a major and growing global issue for economic development and poverty reduction $[1,2]$. Water is essential for food and energy security [3,4], and water-related extremes of flood and droughts have significant economic and social costs [5,6]. With increasing global population and economic development, demand for water and competition between uses and users are on the rise $[7,8]$. Global water consumption is estimated to have increased by 40 percent in the last four decades [8], mostly for irrigation, which represents 70 percent of total global water withdrawals [9]. While everyone depends on freshwater, the importance of groundwater is often overlooked; for example, groundwater provides drinking water for 1.5-3.0 billion people [10]. The current level of global water withdrawals is approaching a planetary boundary, which if crossed would take the Earth system outside a safe operating space for humanity [11]. As result of these pressures, an estimated 4 billion people experience severe water scarcity for at least one month of the year [12]. Local water availability constraints, rapid population growth and urbanization, inadequate infrastructure, and governance shortcomings [13] mean nearly 0.7 billion people lack access to a safely managed drinking water supply [14].

Accelerating climate change is perturbing the global water cycle [15], altering the average patterns of water availability and increasing the magnitude and frequency of water-related extremes in parts of the world. These changes, however, are uncertain and still poorly understood [15-18]. Climate change increases the uncertainty in projections of water supply and demand, and increases the uncertainty in feasibility and economic performance assessments of water infrastructure $[19,20]$.

\subsection{Large River Basins —Character and Importance}

There is no widely accepted criterion for defining "large river basins", either in terms of drainage area or total discharge. Basins exceeding $100,000 \mathrm{~km}^{2}$ in area-of which there are an estimated 130 or so globally (including 22 exceeding 1,000,000 $\mathrm{km}^{2}$ )—could reasonably be considered large. However, rather than use an arbitrary criterion such, we adopt a looser definition that also includes geographically smaller basins where water management challenges are considered 'large', because of one or more of: (i) hydrologic complexity (high flows, hydrologic variability, non-stationarity, surface-groundwater interactions, multiple water sources-rainfall-runoff, snow, glacier melt); (ii) water management complexity (large population, supply-demand imbalance, inter-sectoral competition, rapid demand growth, pollution, high flood and erosion risk, climate change vulnerability),); and (iii) administrative complexity (transboundary coordination or conflict; federate-state-local coordination or conflict; governance complexity-intersecting legal, policy, regulatory frameworks).

Aside from remote and sparsely populated basins in northern Canada and Russia, most of the geographically largest river basins in the world are also international transboundary basins. A total of 286 river international transboundary river basins have been identified (spanning 151 countries and home to more than 40 percent of the global population); 80 percent of the total area and population of the transboundary basins is associated with the largest 156 basins [21]. Larger river basins tend to have a higher economic dependence on water resources, and the 14 basins with the greater economic dependence on water are home to almost 50 percent of the population of all transboundary basins-nearly 1.4 billion people [21]. In addition to international transboundary rivers, large basins within federal countries-such as the Murray-Darling in Australia-represent complex resource management challenges [22].

As well as the economic importance and the associated social values of large river basins, these systems are critical habitat for freshwater biodiversity. Rivers, lakes, and other 'wetlands' occupy just 0.8 percent of the Earth's surface but support 6 percent of all described species including 35 percent of all vertebrates [23], especially fish. Large rivers with higher flow volumes tend to support more fish species, and tropical rivers tend to have higher levels of species richness. The highest levels of riverine fish species richness are found in the Amazon, Orinoco, Tocantins, and the Paraná in South America; the Congo, the Niger Delta, and the Ogooue in Africa; and the Yangtze, Pearl, Brahmaputra, Ganges, Mekong, Chao Phraya, Sittang, and Irrawaddy in Asia [24]. Large rivers are also especially important 
for freshwater megafauna with slow life-history strategies and complex habitat requirements [25]. Globally, freshwater megafauna populations declined by 88\% from 1970 to 2012, with mega-fishes exhibiting the greatest global decline (-94\%) [25]. These major biodiversity declines highlight the conflicts between economic development and environmental protection and conservation in large river basins.

Large river basins present particular challenges and opportunities for the use of emerging technologies in support of water resources management. Geographically, large basins typically traverse a wide range of hydroclimatic regimes, and processes that characterize basin-scale hydrological behavior take place at multiple scales. These give rise to technical challenges for the design and operation of hydrometeorological data collection systems, including the integration of ground-based and remote observations. Because they often span multiple jurisdictions-within and, or between countries-large basins have institutional complexities for coordinated data collection, sharing and analysis, as well as for decision making and for coordinated real-time operational management.

\subsection{Water Security as an Objective for IWRM}

Integrated water resources management (IWRM) has been vigorously promoted by the international development community as a set of principles and a best practice process for planning and managing water resources [26]. IWRM has also however, been strongly criticized from both technical standpoints (for being too vague to have real utility for practical implementation [27]) and from political economy standpoints (having been dubbed "soft coercive hegemony" [28]). We find that accepting some key principles of IWRM (e.g., water systems focus, data/analytical foundation, participatory planning) but shifting to a medium-long term 'water security' outcome focus, helps to better define desired economic, social and environmental outcomes from water, and identify specific interventions to help achieve these. 'Water security' is thus conceptualized as the relationships between the water endowment, the water sector architecture (institutions and infrastructure), water sector performance (resource management, service delivery and risk mitigation) and the outcomes from how water is managed and used (Figure 1). A recent example of the application of this conceptualization is a comprehensive water security diagnostic for Pakistan [29].

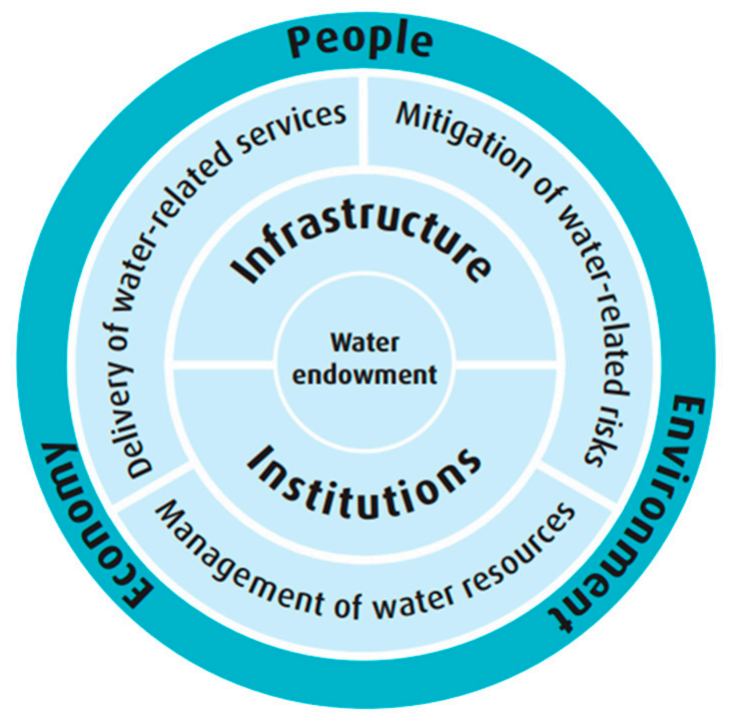

Figure 1. Conceptual framework for water security. 
Water resources management is integral to sustainable development. In 2015, all 193 Member States of the United Nations General Assembly agreed to the 2030 Agenda for Sustainable Development and established 17 Sustainable Development Goals (SDGs). This is a plan to "end poverty in all its forms" and to "shift the world to a sustainable and resilient path". SDG 6-Ensure availability and sustainable management of water and sanitation for all—considers not just water supply and sanitation services, but also water scarcity and water use efficiency, water quality and wastewater treatment, water ecosystems, as well as institutional aspects of water resources management (including IWRM implementation) and cooperation [30]. Other aspects of water security (such as water-related disasters) are captured by other SDGs.

In this paper, we review the application of "disruptive technologies" in water resources management in large river basins, through this water security lens. We consider how these technologies can assist delivering better outcomes or deliver outcomes more efficiently or cost effectively. We discuss the roles of different actors and institutions, and consider risks associated with the adoption of these technologies and the barriers to widespread adoption.

\subsection{Role of Technology in Water Management}

Technology has multiple roles in water management, across the spheres of infrastructure design, systems planning, real-time operations. These can be considered in a matrix with the key areas of water resource management, irrigation management, water supply (and treatment) and sanitation, and environmental water management. Here, we focus on decision making-at both planning and operational time scales-for water resources management. This includes river basin planning; water allocation planning; flood and drought outlooks, forecasts and warnings; and the real-time operational management of water resources infrastructure. However, these boundaries are not tightly delineated, and many of the technologies discussed have application into other aspects of water management as well. For these selected focal areas of water resources management, we consider how 'data' is transformed into 'information' and then 'knowledge', and how these are then used in decision making for action. Along this 'value chain', we thus consider the collection, transmission, storage, management, and sharing of data. Then the ways in which data is transformed into information and thence into knowledge, and how information and knowledge are stored, managed, shared, visualized, and otherwise communicated. We consider the decision process and the roles of multiple actors in this process, and how decisions are communicated and then actioned. Beyond the 'hydro-informatics' elements of technology, there are innovative technologies for operations and stakeholder interaction. With respect to SDG 6, a brief introduction to some technology opportunities is provided by [31,32].

\section{Disruptive Technologies}

Disruptive technology is commonly defined as "technology that can fundamentally change not only established technologies but also the rules and business models of a given market, and often business and society overall"; the term (and concept) was first introduced in the mid-1990s by Harvard Business School scholars in the context of business innovation [33]. Disruptive technologies are now showing much promise in every field of development [34]. The evolution of these technologies is accelerating and disrupting traditional approaches to water planning and management. The key relevant technologies are summarized in Table 1 with implications on their application to water resource management in large river basins.

\subsection{Technology Evolution}

Technological evolution has influenced the use of water resources for millennia. However, in recent years, there has been an acceleration in the development of new tools and technologies of relevance for water resources management (Figure 2). Many factors, however, affect the adoption of emerging technologies, including institutional capacity, the enabling policy and institutional environment, resource availability, competing priorities, access to global good practice, intellectual property, and 
the agility of governments, the private sector, academia, and other actors. These factors have meant heterogeneous but overall slow uptake and diffusion of new technologies. Some technologies that were deployed in the developed world more than a century ago, are only now being adopted across the developing world. However, much of the developing world has a 'last mover' advantage, with the potential to leapfrog old ways and adopt new approaches more rapidly than the developmental paradigm allowed in the developed world. While there have been many challenges in leapfrogging in some areas, including for environmental sustainability and indeed for river basin management [35], information and communication technology leapfrogging is beginning to show real impact in spite of "tech transfer" and "absorptive capacity" issues [36], including through rapid adoption of mobile technologies and leveraging the large data sets generated by some developing countries [37].

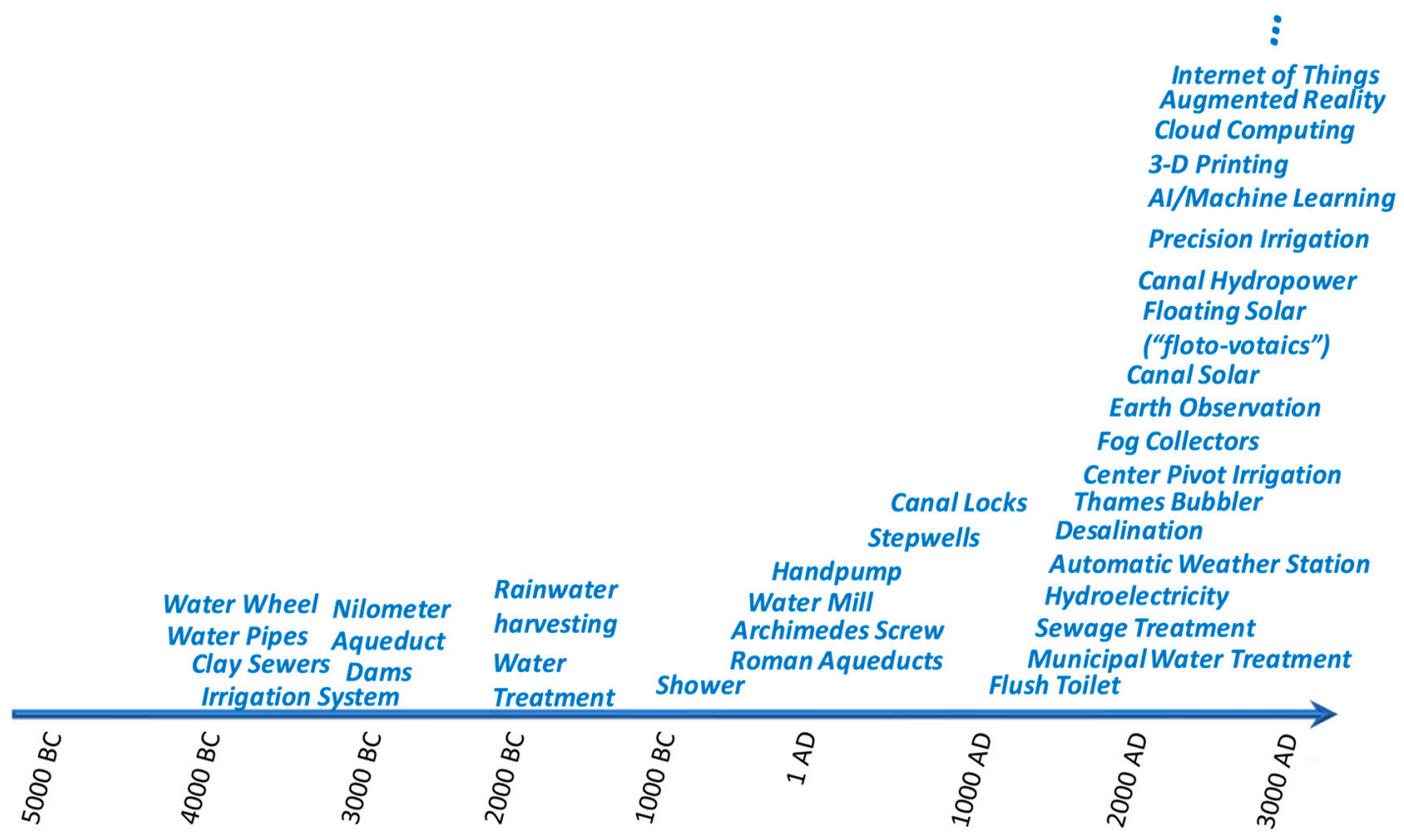

Figure 2. Timeline of water technology evolution.

Here, we classify disruptive technologies according to where they can be most disruptive: (i) decision-making, (ii) operations, and (iii) stakeholder interaction (Figure 3).

\subsection{Technology Appplications}

Traditional investments in water resources in the developing world have seldom been conceived, implemented, or operated from a holistic multi-sectoral basin perspective. They often are based on old technologies and have high operational and maintenance costs that are seldom met, leading to poor service delivery exacerbated by deferred maintenance as they age. Even basic monitoring data are usually not accessible in real-time and require different 'ringfenced' legacy software that are not inter-operable. 


\section{A new world of "Disruptive Technology"}

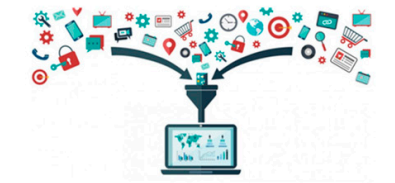

"Disrupt" data value chains

- Data Collection: Monitoring/Surveys (in-situ sensors/loT/Biometrics), earth observation (satellite, aerial geophysical surveys, UAVs), crowdsourcing, digitization..

- Data Management: Telemetry, 5G, cloud services, open data, Blockchain, ...

- Data Analysis: Big data, Geospatial/ Al/Machine Learning, modeling/ scenario analysis, script repositories, quantum computing...

- Data Access: Online services, open data APIs, data visualization, gamification, mixed realityAR/VR, ...

- Outreach: Platforms/Social Media/Portals/ Apps/e-books/Competitions...

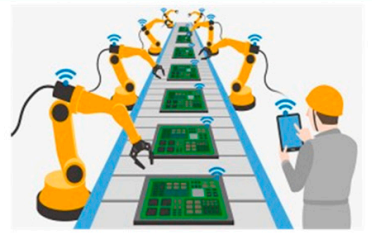

"Disrupt" production value chains

- 3D/4D printing/additive manufacturing (incl. low-cost 3D printed monitoring systems)...

- Automation/SCADA...

- Robotics/Autonomous transport..

- Advanced materials/nanotech/ biotech/genomics/energy tech/green tech, ag tech, modern irrigation, ultrasonic algae control, fog collection.

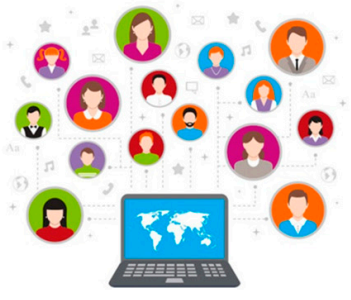

"Disrupt" stakeholder value chains

- Virtual social networks/ digital platforms...

- Sharing economy...

- Crowdsourcing, gamification, competitions (e.g. hackathons, appathons...)

- Blockchain-enabled value chains

- Mobile money, fintech, cryptocurrency...

- Maker movement/DIY/Tech Incubators...

- Virtual learning/re-skilling...

Figure 3. Typology of 'disruptive' technologies.

One of the main ways in which modern technology is reshaping water resources planning and management is through 'disrupting' the data value chain (Figure 4). This is manifested through new inexpensive sensors for in-situ monitoring (tending towards an expansive 'internet of things'), increasingly powerful Earth observations from satellites and drones/unmanned aerial vehicles (UAVs) to provide synoptic views of topography (including high-resolution digital elevation models to identify flood-prone areas and support hydrodynamic modeling), climate, water levels, flows, snow cover, inundated areas, landcover, watershed status, and even some aspects of water quality and groundwater. Earth observations [22], with near global consistent coverage, is rapidly becoming a game-changer for synoptic observations in large basins, where the resolution of even the free resources from NASA and ESA are often adequate for useful water resources analytics. New unmanned on-water and under-water vehicles show promise; they can be outfitted with sensors and autonomous (single or swarm) capability for surveying large water bodies (e.g., for bathymetry, hydraulic safety, water quality, or fish stock assessments).

New analytical tools, increasingly cloud-based-including at the global level, assimilate available data and generate estimates of a range of critical parameters related to snowmelt estimation, water balance, water accounting (e.g., WA+, WAPOR) [38,39], scenario analysis, and forecasts to create 'digital twins' of basins to facilitate analyses. These enable access to curated archives and real-time estimates of the water status for any basin anywhere in the world to support both strategic planning and tactical operations through data visualization, early alerts/warnings, and the development of interactive packaging for data, analytics, and knowledge. Examples include interactive portals, mobile phone applications, and dynamic e-books. These support decisions at all levels, from simple scoping of water resources development, to detailed planning with stakeholder involvement/outreach, as well as real-time operations. Additional systems related to data/text mining, social media integration, advanced cloud-based modeling, machine learning/AI, or 'bots' can help bring in an additional automation and integrated perspectives to support decision-making. 


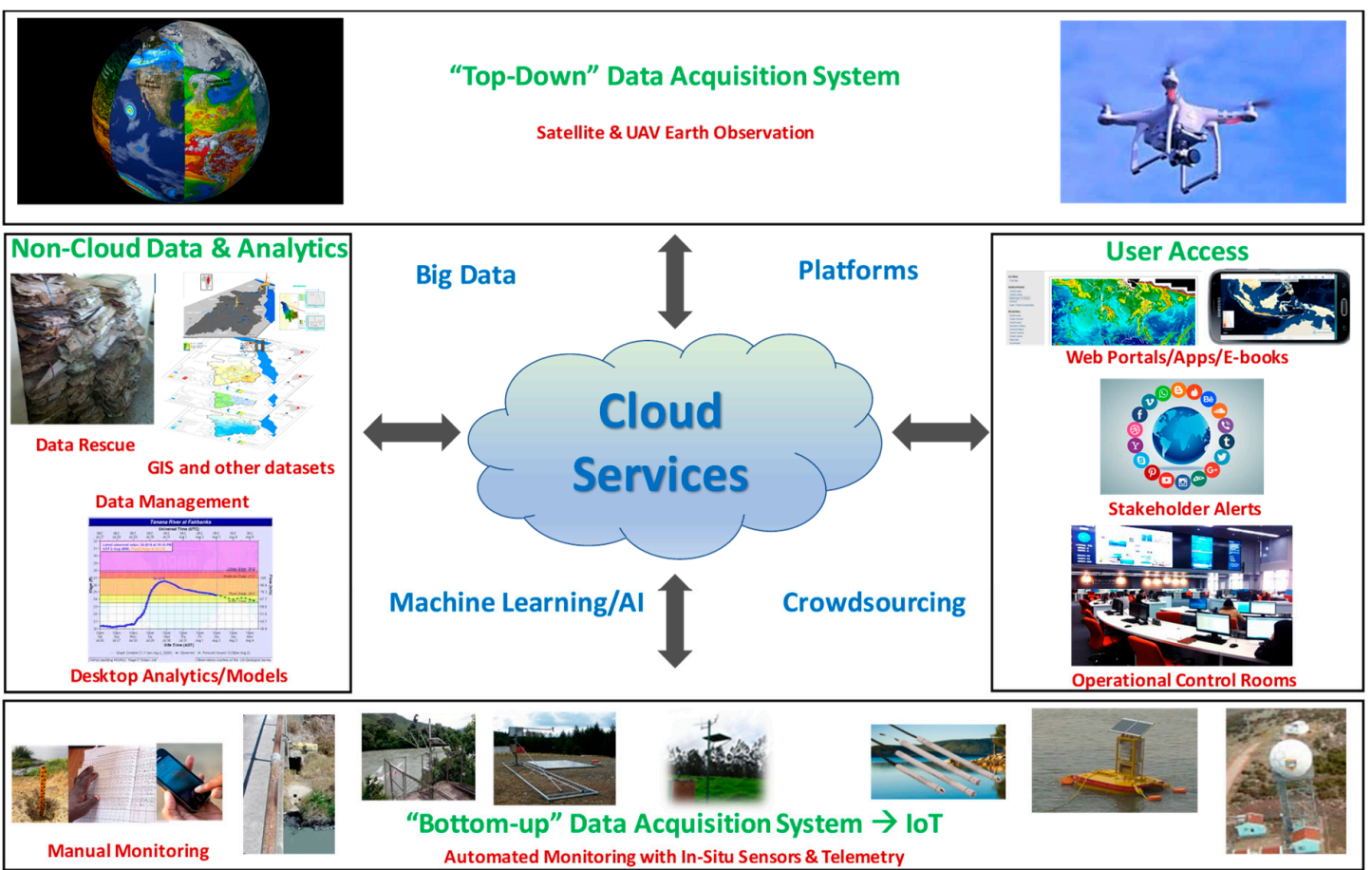

Figure 4. Modernizing the data value chain (Data $\rightarrow$ Information $\rightarrow$ Knowledge $\rightarrow$ Decision Support).

These technologies are helping water managers reimagine the way information-based decisions can be made for smart water resources planning and management and are allowing development of integrated basin/aquifer plans based on both analytical and stakeholder approaches. Technologies have made possible new approaches to use and conserve water and administer usage caps (e.g., using satellite-derived actual evapotranspiration estimates), adopting a systems perspective to improve agricultural water productivity, benchmark systems, and incentivize sustainability. New in-situ and Earth observation monitoring and analytics allow for development and customization of tools for water planning, allocation, and coordinated water infrastructure operations in an integrated multi-sectoral systems perspective. Water infrastructure can now be operated in a more coordinated systems context for multiple objectives ranging from service delivery to climate resilience. Continuous innovation, piloting, and learning from global good practices enables quick scaling-up of new technologies and enables more adaptive management.

3D printing, robotics, automated transport, advanced materials, nanotech, biotech, and cleantech are supporting new operational systems that represent a paradigm shifts away from traditional approaches. Examples include irrigation systems that improve water productivity and field-level water use efficiency (especially when combined with policies such as limits on water abstraction); 3D printed monitoring stations (e.g., 3D-PAWS [40]) that reduce costs for monitoring weather and water levels; and ultrasonic control systems (successfully piloted in Lake Quaroun in Lebanon) that can mitigate algae-related water quality problems.

Platforms are emerging to enable people to work together in new ways in the sharing economy, including fintech, crowdsourcing, crowdfunding, block-chain enabled supply chains, asset sharing systems, Digital ID enabled e-governance, and open learning platforms. Many of these platforms have application in water management in large basins, including online/mobile platforms to support learning or interactions among remote or disperse water user associations, and platforms to help farmers access global marketplaces online, with feedbacks into irrigation water requirements. 


\subsection{Implications for Large Basins}

The implications of these new technologies, with a focus on digital technologies, for water resources planning and management in large basins, are summarized in Table 1. Major changes in water management around the world are likely in very short timeframes. Ref [41] Many of the initial impacts will come from the plummeting costs of sensors, mobile devices and connectivity, cloud services (including to process increasingly powerful earth observation and other big data), interoperability due to online data standards and protocols, and increasing digital literacy.

Water data could be used primarily for water assessments, evaluations, operations, foresight, design, accountability, and education [42]. Many of these are useful at different scales-from monitoring progress towards the SDG-6 global indicators to helping design a culvert.

Many countries are modernizing their water resources institutions and developing national water resource information systems and analytics to support basin planning and disaster management. Some are also strengthening ties among government, academic, civil society organizations (CSO), and private sector institutions to develop a broad stakeholder base for this transformation. Modern water information systems require integration of data (from global, regional, national, to local sources), data quality management, conversion to interoperable data services, and development of interactive dashboards to help access and visualize data services and associated analytics in appropriate formats to support decisions.

Large basins will especially benefit from these changes given both the challenges (e.g., the need to integrate data across large areas; multiple stakeholders wishing to inform coordinated decisions; large water infrastructure investments) and the opportunities of large basins (e.g., application of free Earth observations in the 10-250 m resolution range; the ability to deliver reach large numbers of remote beneficiaries with valuable data services).

Institutions such as the Mekong River Commission and the various Nile Basin Initiative centers have demonstrated the utility of modern data and analytics in basin planning and hydro-meteorological data integration. Other large basins (e.g., the Congo, Ganges-Brahmaputra-Meghna) are in the nascent stages of this journey given capacity constraints and transboundary cooperation challenges.

Many countries are modernizing their water information systems taking advantage of new technologies. The United States and Australia are improving their already well-established systems facilitated by strong national institutions. Europe is increasingly building on its regional institutions (e.g., European Centre for Medium-Range Weather Forecasts, European Organisation for the Exploitation of Meteorological Satellites, Joint Research Centre of the European Commission) to help countries access better data and analytics. China is utilizing evapotranspiration estimates derived from Earth observations to improve irrigation management $[43,44]$ and India is enhancing its national water resources information system [45].

Estimates based on satellite products or global models are increasingly found to be comparable with those based on in-situ observations [46,47]. These techniques, especially when enhanced by a new generation of artificial intelligence (AI)/machine-learning (ML) algorithms and global models, can revolutionize water resources management even in data-poor environments. When accessed through customized interactive dashboards, this information can be especially useful for estimating parts of the water balance, estimating flooding areas, making customized weather/hydrologic/inundation forecasts, managing large water demands (e.g., agriculture) and system losses, while enhancing and benchmarking water productivity $[48,49]$. 
Table 1. Summary of disruptive technologies relevant to water management in large basins.

\begin{tabular}{|c|c|c|c|}
\hline Technology & Description & Implications for Large Basins & References \\
\hline $\begin{array}{l}\text { In-situ Sensors and } \\
\text { Internet of Things (IoT) }\end{array}$ & $\begin{array}{l}\text { Sensor is a generic term for devices capable of sensing external } \\
\text { stimuli (e.g., force, flow, acceleration, light, sound, vibration, } \\
\text { humidity, temperature, pressure) and act upon those readings } \\
\text { (e.g., recording, reporting, reacting). IoT refers to a set of physical } \\
\text { objects with embedded ubiquitous sensors connected to } \\
\text { networks (e.g., telemetry) and interfacing with } \\
\text { analytics/applications that support real-time management. }\end{array}$ & $\begin{array}{l}\text { Inexpensive in-situ real-time monitoring networks (e.g., for snow, flows, soil } \\
\text { moisture, groundwater, water quality) especially with an internet-of-things } \\
\text { approach supported by effective telemetry (GSM, satellite, radio, blue-tooth, } \\
\text { broadband, etc.) for natural (e.g., streams, rivers, lakes, coasts) and man-made } \\
\text { systems (e.g., canals, pipes) }\end{array}$ & {$[50,51]$} \\
\hline $\begin{array}{c}\text { Earth Observation and } \\
\text { Geospatial }\end{array}$ & $\begin{array}{l}\text { Remote sensing (acquisition and processing of information } \\
\text { without making contact) using satellites, drones/UAVs and other } \\
\text { aircraft. Analytics using modern GIS and Remote Sensing } \\
\text { Software and Services. }\end{array}$ & $\begin{array}{l}\text { Satellite data products for weather, land cover, water levels, evapotranspiration, } \\
\text { flow, and groundwater change for large basins. Heliborne surveys to explore } \\
\text { geological structure; drone surveys of streambanks; LiDAR surveys for } \\
\text { flood-prone areas; drone/UAV surveys. Geospatial data processing tools (from } \\
\text { desktop to online systems) support applications from data visualization to } \\
\text { complex modeling. }\end{array}$ & {$[52-54]$} \\
\hline Cloud Services & $\begin{array}{l}\text { A cloud service is any service made available to users on demand } \\
\text { via the internet from cloud-computing servers. Cloud services } \\
\text { are designed to provide easy, scalable access to applications, } \\
\text { resources and services, and are fully managed by a cloud services } \\
\text { provider. As cloud services become more ubiquitous, cheaper, } \\
\text { and more secure, they offer more opportunities for combining } \\
\text { data in new ways and making them accessible on multiple } \\
\text { devices in any setting. }\end{array}$ & $\begin{array}{l}\text { 'Big data' analytics especially when supported by new data science advances in } \\
\text { scripting, online analytics, modelling, and visualizations. These services can be } \\
\text { free, or subscription based (e.g., Google Earth Engine, Open Data Cube, etc.) }\end{array}$ & {$[52,55-57]$} \\
\hline $\begin{array}{l}\text { Open Data/Analytics } \\
\text { and Standards }\end{array}$ & $\begin{array}{l}\text { Open standards for data/data and analytics services (e.g., Open } \\
\text { Geospatial Consortium (OGC), Open APIs) are helping make } \\
\text { data and analytics more accessible in online contexts. The } \\
\text { concept of AI tries to mimic human intelligence in machines. ML } \\
\text { enables computer programs to become self-learning through data } \\
\text { mining and supervised, unsupervised, or hybrid training } \\
\text { systems. Many countries are encouraging policies to promote } \\
\text { more data accessibility in the public domain. Blockchain could } \\
\text { help use a distributed ledger technology that can help make } \\
\text { transactions relatively tamper-proof. }\end{array}$ & $\begin{array}{l}\text { Open standards help make systems interoperable. Some of these (e.g., WaterML } \\
\text { from OGC) have a lot of potential if their use becomes widespread. Open data can } \\
\text { be particularly useful for weather, streamflows, soil moisture, groundwater, water } \\
\text { quality, crop yields, etc. to facilitate decision support and training for machine } \\
\text { learning/AI systems. Models (especially in the public domain) for water balance } \\
\text { or water systems analysis are slowly moving to cloud platforms and could disrupt } \\
\text { traditional desktop modeling when better established. ML/AI systems can help } \\
\text { integrate disparate information, power automation, develop chatbots, and aid } \\
\text { language translation. Blockchain could improve transparency and reliability of } \\
\text { data reporting, smart contracts, and water administration. }\end{array}$ & [58-63] \\
\hline $\begin{array}{l}\text { User Interfaces (portals, } \\
\text { mobile Apps, } \\
\text { augmented/virtual reality) }\end{array}$ & $\begin{array}{l}\text { Rapid advances are being made in providing access to data, } \\
\text { analytics, and knowledge to support learning and } \\
\text { decision-support for end-users, as well as new ways to } \\
\text { crowdsource user observations, surveys, and other inputs. }\end{array}$ & $\begin{array}{l}\text { Interfaces for modern operational control rooms/water centers, smartphones, } \\
\text { tablets, computers, augmented/virtual/mixed reality devices to access, visualize, } \\
\text { and analyze basin data from in-situ sensors, Earth observations, model results, etc. }\end{array}$ & {$[64,65]$} \\
\hline Stakeholder Interaction & $\begin{array}{l}\text { Tremendous improvements are being made in connectivity } \\
\text { (mobile voice and data access; broadband), and in } \\
\text { e-government/private sector online services. }\end{array}$ & $\begin{array}{l}\text { Improved connectivity through mobile devices and online services can usher in a } \\
\text { new paradigm for stakeholders to work together and access global good practice }\end{array}$ & [66-68] \\
\hline
\end{tabular}




\section{Institutional Roles}

Traditionally, water resources institutions have faced the challenge of inefficient workflows, low capacity, poor coordination across sectors and governance levels, poor integration with other kinds of institutions (e.g., academia, private sector), limited transparency, and inadequate alacrity in learning from global good practices. New technologies are enabling improvements in information interoperability [63] and institutional infrastructure that can be developed at reasonable cost (e.g., ecosystems of computers, tablets, and smartphones and related Apps; shared audio/videoconferencing, shared communication, and touchscreen access resources; dynamic physical-computer modeling approaches [e.g., [69]). These can be co-located in clusters such as water centers that allow for co-location of representatives from related organizations that need to work together (e.g., the National Water Center in the United States) to develop and use shared products (e.g., the National Water Model [70]). These approaches could be adopted in many countries and transboundary basins where shared personnel and tools could 'disrupt' traditional 'siloed' approaches.

New technologies are also fundamentally changing the notion of capacity-building, with services, automation, and interfaces reducing the need for laborious and time-consuming issues related to access restrictions, digitization, formats, fragmented desktop analysis, and dissemination on a case-by-case basis, all with only a few people having access to even view the data and products. New more automated systems enable wider access and a different kind of capacity development, avoiding the need for reinventing similar systems at great cost and with limited new functionality. These systems can increase levels of collaboration between agencies, through shared data, analytics, and visualization services. All stakeholders can leverage the learning and collaboration systems supported by the internet and high-speed connectivity, in order to learn rapidly from and contribute to global good practices. New technologies can help redesign stakeholder consultation, climate hazard insurance, payments for ecosystem services, by connecting stakeholders and by accessing new data analytics. Different institutions have different roles in this evolving world (Table 2).

Table 2. Institutional roles in the disruption process.

\begin{tabular}{|c|c|}
\hline Institution & Potential Role in the Disruption Process \\
\hline Governments & $\begin{array}{l}\text { Enabling policy environment for innovation (e.g., open data policies, incentivizing } \\
\text { collaboration and innovation, building/facilitating the backbone cyberinfrastructure, } \\
\text { improving internal and external collaboration and shared vision, creating } \\
\text { internship/visiting expert programs, open transparent procurement and learning expos to } \\
\text { facilitate innovation, shared vision and collaborative decision-making) as well as } \\
\text { managing the downside risks (e.g., obsolete jobs, privacy, cybersecurity). The role would } \\
\text { be customized to the level of government institution (from national to provincial to local) } \\
\text { considering the opposite implications of the principles of subsidiarity and economies } \\
\text { of scale. }\end{array}$ \\
\hline Academia & $\begin{array}{l}\text { Improving research and data/tools/literature in the public domain, educate existing water } \\
\text { professionals and a new generation of water professionals on the potential for new } \\
\text { technologies, collaborative research and internship programs, contributions in hackathons } \\
\text { and other competitions. }\end{array}$ \\
\hline Private Sector & $\begin{array}{l}\text { Develop innovative approaches that respond to challenges faced by various stakeholders, } \\
\text { showcase new approaches, explore opportunities to demonstrate proof-of-concept. }\end{array}$ \\
\hline $\begin{array}{l}\text { Regional and Global } \\
\text { Institutions }\end{array}$ & $\begin{array}{l}\text { Facilitate access to finance, knowledge of regional and global good practices, learning and } \\
\text { collaboration (e.g., for transboundary basin organizations, multilateral or bilateral } \\
\text { development organizations, large CSO, partnerships, etc.) related to the use of new } \\
\text { technologies and sharing lessons from implementation experience. }\end{array}$ \\
\hline Community & $\begin{array}{l}\text { Improve awareness of emerging disruptive technologies and role of the public in } \\
\text { highlighting opportunities and concerns and demanding and using open data for action } \\
\text { and social media. Increase and improve public involvement through CSO facilitation, } \\
\text { citizen science approaches, and crowdsourcing/crowdfunding innovations. }\end{array}$ \\
\hline
\end{tabular}


Water sector institutions have both management and governance roles [71] and both these roles can be enhanced through technology. For example, in the case of groundwater management in large areas, improved monitoring using in-situ sensors (e.g., for extraction, use, quality, recharge), Earth observations (e.g., for evapotranspiration estimates and gravity-based water equivalent changes) and improved models, could improve resource management through regulating groundwater pumping (volumes and timing) or determining bore spacings. Modern communication including for automated collection of fines, could improve governance to promote resource management goals of equity, efficiency, conservation, and sustainability. New technologies could be particularly useful in transboundary waters contexts, with multiple options now available for estimating resource extent and condition, and other key water resources variables.

A key constraint in reaching the potential the various technologies is data availability. This could be overcome by wider government adoption of an open data approach. For example, the California Open and Transparent Water Data Act requires the state Department of Water Resources to create, operate, and maintain an open-access state-wide integrated water data platform [72].

\section{Benefits, Risks, and Barriers to Adoption}

The technologies discussed herein offer important technical and governance benefits compared to traditional approaches. They can increase robustness in decision making, as decisions are more likely to be based on more complete information (e.g., from weather and other apps, portals, decision support systems). They can increase the timeliness and accuracy of real-time and near real-time decisions through greater use of automation and rapid and reliable communications. They can reduce the costs of basin planning and management (e.g., lower traditional hydromet monitoring costs, reduced redundancy, and increased economies of scale from online services). They benefit end-users through better information and decision-support and enhanced mechanisms to connect stakeholders and global good practice (e.g., through social media and packaged curated content). They provide enhance trust and cooperation across sectors and regions (including transboundary) and can support more democratic decision-making through open and equal access to data and information.

While disruptive technologies (even while often benefitting from centralized platforms and standards) are encouraging a move away from top-down centralized decision processes, their adoption does not guarantee this positive shift. There are many instances of the deployment of disruptive technologies in top-down or centralized decision making without adequate stakeholder consultation. Understanding the governance context for disruptive technology deployment is therefore critical, as is explicit consideration of how this context determines whether new technologies enhance or hinder processes of stakeholder participation and empowerment [73,74].

In addition to these potential negative consequences, there are significant barriers to widespread and rapid uptake of these technologies. Adoption requires a considerable range of new technical skills, many of which are not standard in university water management curricula. In addition to awareness-building, there is a need to improve the sector skill-base through training, recruiting/ insourcing appropriate cutting-edge technology skills, and building partnerships. As with any new technology, the need to invest in new infrastructure has budget implications, and while costs for many of the technologies are rapidly reducing, governments may be reluctant to invest in what may be perceived as non-standard equipment. As these technologies are evolving rapidly, there will be pressure to update and upgrade more frequently than in the past. With the accelerated risk of obsolescence, it will be important to move to new adaptable cloud-based approaches that allow rapid upgrading of systems. This highlights the need for changed mindsets to help water resource managers and decision makers step out of the 'comfort zone' to recognize this new world of rapidly evolving technologies.

As well as barriers to adoption, there are some significant risks. Effective management of privacy and cybersecurity risks requires good institutional policies, frameworks, and systems [71]. There are implications for professional employment, since as with any technological change, large numbers of employees will increasingly find there is diminishing need for traditional, manual jobs as these become 
automated (e.g., gauge readers, analysts, desktop modelers, translators, etc.). Employers will need to recognize these trends and institute retraining or retrenchment/skill upgrading/replacement programs for effective workforce management. There is a risk that the digital divide will become greater-with many countries, and communities within countries, unable to access the disruptions that seem to be changing life for the better in other places and for other people. This will require increased emphasis on low-cost or free open public-domain systems and the ability to create and use more global platforms.

\section{Conclusions and Forward Look}

A new world of innovative technologies has the potential to 'disrupt' traditional approaches to water resources management in large basins. The widespread operationalization of the fuzzy concept of IWRM is now within reach, with new ways to strengthen the information, institution, and investment foundations of IWRM.

Looking ahead, there are two mutually reinforcing aspects that will help make the rate of technological adoption exponential. First, technology is evolving at a blistering pace, dropping the costs for every process and enabling actions that were not even considered in the realm of possibility a few years ago. Second, the incremental adoption of some of these technological options in water resources planning and management are generating lessons that can inspire others to do even better as adoption spreads.

These changes are likely to lead to a new way of reconsidering data and analytical sovereignty as data and analytics (e.g., for droughts, floods, basin scenario planning) become increasingly global, fueled by machine learning that builds on opening up of data access for training. Water withdrawal and net consumption will be closely tracked and monitored (with a combination of in-situ sensors and Earth observation) to improve systems management and benchmarking. Large-basin analytics could become virtually free for users with global, regional, and national development agencies absorbing the costs of development and any subscription services. Services for end users (e.g., farmers) could also become free or low-cost services and help improve water management at the user level and deliver improved productivity.

Collectively, these changes can help to 'democratize' water management through improved access to data and information, but increased attention will need to be given to equity in technology access. Disruptive technologies will require adjustments to how water professionals are trained, an increasing adaptiveness in water resources planning and operations, and careful consideration of privacy and cybersecurity issues. Especially as the world struggles with the ongoing COVID-19 pandemic experience, there is an increasing appreciation of the use of such new technologies to help conceive, remotely monitor, and manage water resource systems and related investments. Strong leadership to create an enabling environment to improve awareness and skills related to new technologies to realize the promised benefits and effectively manage risks is essential to facilitate this modernized approach to planning and managing large basins.

Author Contributions: Conceptualization, N.R.H. and W.Y.; Methodology, N.R.H. and W.Y.; Writing-Original Draft Preparation, N.R.H.; Writing-Review and Editing, W.Y. All authors have read and agreed to the published version of the manuscript.

Funding: This research received no external funding.

Acknowledgments: We thank three anonymous reviewers for improvements to the manuscript.

Conflicts of Interest: The authors declare no conflict of interest.

\section{References}

1. Oki, T.; Kanae, S. Global hydrological cycles and world water resources. Science 2006, 313, $1068-1072$. [CrossRef] [PubMed]

2. Postel, S.L.; Daily, G.C.; Ehrlich, P.R. Human appropriation of renewable fresh water. Science 1996, 271, 785-788. [CrossRef] 
3. Lotze-Campen, H.; Müller, C.; Bondeau, A.; Rost, S.; Popp, A.; Lucht, W. Global food demand, productivity growth, and the scarcity of land and water resources: A spatially explicit mathematical programming approach. Agric. Econ. 2008, 39, 325-338. [CrossRef]

4. Wan, L.; Wang, C.; Cai, W. Impacts on water consumption of power sector in major emitting economies under INDC and longer-term mitigation scenarios: An input-output based hybrid approach. Appl. Energy 2016, 184, 26-39. [CrossRef]

5. Centre for Research on the Epidemiology of Disasters. EM-DAT-The International Disaster Database. Available online: http://www.emdat.be/database (accessed on 26 May 2020).

6. Carolwicz, M. Natural hazards need not lead to natural disasters. EOS 1996, 77, 149-153. [CrossRef]

7. Distefano, T.; Kelly, S. Are we in deep water? Water scarcity and its limits to economic growth. Ecol. Econ. 2017, 142, 130-147. [CrossRef]

8. Qin, Y.; Mueller, N.D.; Siebert, S.; Jackson, R.B.; AghaKouchak, A.; Zimmerman, J.B.; Tong, D.; Hong, C.; Davis, S.J. Flexibility and intensity of global water use. Nat. Sust. 2019, 2, 515-523. [CrossRef]

9. WWAP (World Water Assessment Program). The United Nations World Water Development Report 3: Water in a Changing World; UNESCO: Paris, France; Earthscan: London, UK, 2009.

10. MEA (Millennium Ecosystem Assessment). Ecosystems and Human Well-Being: Wetlands and Water Synthesis; World Resources Institute: Washington, DC, USA, 2005.

11. Steffen, W.; Richardson, K.; Rockström, J.; Cornell, S.E.; Fetzer, I.; Bennett, E.; Biggs, R.; Carpenter, S.R.; De Vries, W.; De Wit, C.A.; et al. Planetary boundaries: Guiding human development on a changing planet. Science 2015, 347. [CrossRef]

12. Mekonnen, M.M.; Hoekstra, A.Y. Four billion people facing severe water scarcity. Sci. Adv. 2016, 2, e1500323. [CrossRef]

13. IEG (Independent Evaluation Group). A Thirst for Change. World Bank Publications; No. 29345; World Bank: Washington, DC, USA, 2017.

14. WHO and UNICEF (World Health Organization and UNICEF Joint Monitoring Programme (JMP). Progress on Drinking Water and Sanitation, 2015 Update and MDG Assessment. Available online: http://water.org/ water-crisis/water-sanitation-facts/ (accessed on 10 May 2020).

15. IPCC (Intergovernmental Panel on Climate Change). Climate Change 2014: Impacts, Adaptation, and Vulnerability. Part A: Global and Sectoral Aspects. Contribution of Working Group II to the 5th Assessment Report of the IPCC; Field, C.B., Barros, V.R., Dokken, D.J., Mach, K.J., Mastrandrea, M.D., Bilir, T.E., Chatterjee, M., Ebi, K.L., Estrada, Y.O., Genova, R.C., et al., Eds.; Cambridge University Press: Cambridge, UK; New York, NY, USA, 2014.

16. Wasko, C.; Sharma, A. Global assessment of flood and storm extremes with increased temperatures. Sci. Rep. 2017, 7, 7945. [CrossRef]

17. Sharma, A.; Wasko, C.; Lettenmaier, D.P. If precipitation extremes are increasing, why aren't floods? Water Resour. Res. 2018. [CrossRef]

18. Dai, A. Increasing drought under global warming in observations and models. Nat. Clim. Chang. 2012, 3, 52-58. [CrossRef]

19. World Bank. The Critical Face of Climate Change-Water; World Bank: Washington, DC, USA, 2016.

20. Ray, P.A.; Brown, C.M. Confronting Climate Uncertainty in Water Resources Planning and Project Design: The Decision Tree Framework; World Bank: Washington, DC, USA, 2015.

21. UNEP-DHI; UNEP. Transboundary River Basins: Status and Trends; United Nations Environment Programme (UNEP): Nairobi, Kenya, 2016.

22. García, L.; Rodríguez, J.; Wijnen, M.; Pakulski, I. Earth Observation for Water Resources Management: Current Use and Future Opportunities for the Water Sector; World Bank: Washington, DC, USA, 2016.

23. Garrick, D.; Anderson, G.; Connell, D.; Pittock, J. Federal rivers: A critical overview of water governance challenges in federal systems. In Federal Rivers: Managing Water in Multi-Layered Political Systems; Garrick, D., Anderson, G., Connell, D., Pittock, J., Eds.; Edward Elgar Publishing: Cheltenham, UK; Northampton, MA, USA, 2014; pp. 3-19.

24. Dudgeon, D.; Arthington, A.H.; Gessner, M.O.; Kawabata, Z.-I.; Knowler, D.J.; Lévêque, C.; Naiman, R.J.; Prieur-Richard, A.-H.; Soto, D.; Stiassny, M.L.J.; et al. Freshwater biodiversity: Importance, threats, status and conservation challenges. Biol. Rev. 2016, 81, 163-182. [CrossRef] [PubMed] 
25. Revenga, C.; Tyrrell, T. Major river basins of the world. In The Wetland Book; Finlayson, C., Milton, G., Prentice, R., Davidson, N., Eds.; Springer: Dordrecht, The Nethrelands, 2016.

26. He, F.; Zarfl, C.; Bremerich, V.; David, J.N.W.; Hogan, Z.; Kalinkat, G.; Tockner, K.; Jähnig, C.J. The global decline of freshwater megafauna. Glob. Chang. Biol. 2019, 1-10. [CrossRef] [PubMed]

27. Rahaman, M.M.; Varis, O. Integrated water resources management: Evolution, prospects and future challenges. Sustai. Sci. Pract. Policy 2005, 1, 15-21. [CrossRef]

28. Biswas, A.K. Integrated water resources management: Is it working? Int. J. Water Resour. Dev. 2008, 24, 5-22. [CrossRef]

29. Allouche, J. The birth and spread of IWRM-A case study of global policy diffusion and translation. Water Altern. 2016, 9, 412-433.

30. Young, W.J.; Anwar, A.; Bhatti, T.; Borgomeo, E.; Davies, S.; Garthwaite, W.R., III; Gilmont, E.M.; Leb, C.; Lytton, L.; Makin, I.; et al. Pakistan: Getting More from Water. Water Security Diagnostic; World Bank: Washington, DC, USA, 2019.

31. United Nations. Sustainable Development Goal 6 Synthesis Report on Water and Sanitation; United Nations: New York, NY, USA, 2018.

32. Borden, C.; Swanson, D.; Young, W. Monitoring SDG progress for water and sanitation: Challenges and opportunities. IAHR Hydrolink 2017, 3, 88-91.

33. Bower, J.L.; Christensen, C.M. Disruptive Technologies: Catching the Wave. Harv. Bus. Rev. 1995, 73, 43-53.

34. E-book Primer on Disruptive Technology, World Bank. Available online: www.appsolutelydigital.com/dt/ (accessed on 10 May 2020).

35. Shah, T.; Makin, I.; Sakthivadivel, R. Limits to leapfrogging: Issues in transposing successful river basin management institutions in the developing world. In Intersectoral Management of River Basins, Proceedings of an International Workshop on Integrated Water Management in Water-Stressed River Basins in Developing Countries: Strategies for Poverty Alleviation and Agricultural Growth, Loskop Dam, South Africa, 16-21 October 2000; Abernethy, C.L., Ed.; International Water Management Institute: Colombo, Sri Lanka, 2001; pp. 89-114.

36. Steinmueller, W.E. ICTs and the possibilities for leapfrogging by developing countries. Int. Labour Rev. 2020, 140, 193-210. [CrossRef]

37. Ciuriak, D.; Ptashkina, M. A Global South Strategy to Leverage the Digital Transformation for Development. World Trade Organization, Enhanced Integrated Framework (EIF) Aid for Trade Series. 2019. Available online: https://ssrn.com/abstract=3405330 (accessed on 10 May 2020).

38. Karimi, P.; Bastiaanssen, W.G.M.; Molden, D. Water Accounting Plus (WA+)—A water accounting procedure for complex river basins based on satellite measurements. Hydrol. Earth Syst. Sci. 2013, 17, 2459-2472. [CrossRef]

39. FAO. Available online: https://wapor.apps.fao.org/home/WAPOR_2/2 (accessed on 10 May 2020).

40. 3D-PAWS. 3D Printed Automatic Weather Station Initiative. Available online: https://www.icdp.ucar.edu/ core-programs/3dpaws/ (accessed on 10 September 2020).

41. World WaterNet. Ultra-Sonic Algae Control Devices and Algae monitoring stations Installed in Lake Qaraoun, Lebanon. 2018. Available online: www.wereldwaternet.nl/en/latest-news/2018/august/ultra-sonicalgae-control-devices-installed-in-lake-qaraoun/ (accessed on 10 September 2020).

42. Bureau of Meteorology. Good Practice Guidelines for Water Data Management Policy: World Water Data Initiative; Bureau of Meteorology: Melbourne, Australia, 2017.

43. Wu, B.; Jiang, L.; Yana, N.; Perry, C.; Zeng, H. Basin-wide evapotranspiration management: Concept and practical application in Hai Basin, China. Agric. Water Manag. 2013, 145, 145-153. [CrossRef]

44. Wu, B.; Meng, J.; Li, Q.; Yan, N.; Du, X.; Zhang, M. Remote sensing-based global crop monitoring: Experiences with China's Cropwatch system. Int. J. Digit. Earth 2014, 7, 113-137. [CrossRef]

45. Central Water Commission. Water Resources Information System. 2019. Available online: Cwc.gov.in/waterresources-information-system-wris (accessed on 10 September 2020).

46. Le, M.-H.; Lakshmi, V.; Bolten, J.; Du Bui, D. Adequacy of satellite-derived precipitation estimate for hydrological modelling in Vietnam basins. J. Hydrol. 2020, 586. [CrossRef]

47. Dandridge, C.; Fang, B.; Lakshmi, V. Downscaling of SMAP soil moisture in the lower Mekong river basin. Water 2020, 12, 56. [CrossRef]

48. Harshadeep, N. Innovations for Sustainable Planning and Management of Watersheds, World Meteorological Organization; World Meteorological Organization: Geneva, Switzerland, 2018; Volume 67. 
49. Harshadeep, N. Spatial agent: Reimagining data \& analytics in an increasingly online world, sector insight. Photogramm. Eng. Remote Sens. 2019, 85, 707-711.

50. Robles, T.; Alcarria, R.; Martin, D.; Morales, A.; Navarro, M.; Calero, R.; Iglesias, S.; López, M. An internet of things-based model for smart water management. In Proceedings of the 28th International Conference on Advanced Information Networking and Applications Workshops, Victoria, BC, Canada, 13-16 May 2014; pp. 821-826. [CrossRef]

51. Perumal, T.; Sulaiman, M.N.; Leong, C.Y. Internet of Things (IoT) enabled water monitoring system. In Proceedings of the IEEE 4th Global Conference on Consumer Electronics (GCCE), Osaka, Japan, 27-30 October 2015; pp. 86-87. [CrossRef]

52. Bucur, A.; Wagner, W.; Elefante, S.; Naeimi, V.; Briese, C. Development of an Earth observation cloud platform in support to water resources monitoring. In Earth Observation Open Science and Innovation. ISSI Scientific Report Series; Mathieu, P.P., Aubrecht, C., Eds.; Springer: Berlin, Germany, 2018; Volume 15. [CrossRef]

53. Lawford, R.; Strauch, A.; Toll, D.; Fekete, B.; Cripe, D. Earth observations for global water security. Curr. Opin. Environ. Sustain. 2013, 5, 633-643. [CrossRef]

54. McCabe, M.F.; Rodell, M.; Alsdorf, D.E.; Miralles, D.G.; Uijlenhoet, R.; Wagner, W.; Lucieer, A.; Houborg, R.; Verhoest, N.E.C.; Franz, T.E.; et al. The future of Earth Observation in hydrology. Hydrol. Earth Syst. Sci. 2017, 21, 3879-3914. [CrossRef]

55. Nie, X.; Fan, T.; Wang, B.; Li, Z.; Shankar, A.; Manickam, A. Big data analytics and IoT in operation safety management in under water management. Comput. Commun. 2020, 154, 188-196. [CrossRef]

56. Lewis, A.; Oliver, S.; Lymburner, L.; Evans, B.; Wyborn, L.; Mueller, N.; Raevski, G.; Hooke, J.; Woodcock, R.; Sixsmith, J.; et al. The Australian Geoscience Data Cube-Foundations and lessons learned. Remote Sens. Environ. 2017, 202, 276-292. [CrossRef]

57. Gorelick, N.; Hancher, M.; Dixon, M.; Ilyushchenko, S.; Thau, D.; Moore, R. Google Earth Engine: Planetary-scale geospatial analysis for everyone. Remote Sens. Environ. 2017, 202, 18-27. [CrossRef]

58. Dogo, E.M.; Salami, A.F.; Nwulu, N.I.; Aigbavboa, C.O. Blockchain and internet of things-based technologies for intelligent water management system. In Artificial Intelligence in IoT. 2019. Transactions on Computational Science and Computational Intelligence; Al-Turjman, F., Ed.; Springer: Berlin, Germany, 2019. [CrossRef]

59. Chohan, U.W. Blockchain and Environmental Sustainability: Case of IBM's Blockchain Water Management. Notes on the 21st Century (CBRI). 2019. Available online: https://ssrn.com/abstract=3334154 (accessed on 10 May 2020).

60. Blodgett, D.; Dornblut, I. (Eds.) OGC WaterML 2: Surface Hydrology Features (HY_Features)—Conceptual Model, Version 1.0; Open Geospatial Consortium: Wayland, MA, USA, 2018. [CrossRef]

61. Khattar, R.; Ames, D.P. A web services-based water data sharing approach using OGC Standards. Open Water J. 2020, 6, 2.

62. Reichstein, M.; Camps-Valls, G.; Stevens, B.; Jung, M.; Denzler, J.; Carvalhais, N.; Prahbat. Deep learning and process understanding for data-driven Earth system science. Nature 2019, 566, 195-204. [CrossRef] [PubMed]

63. World Economic Forum. Harnessing the fourth industrial revolution for water. In Fourth Industrial Revolution for the Earth Series; World Economic Forum: Cologny, Switzerland, 2018; p. 25.

64. Wang, J.; Wang, T.; Zhang, J.; Tan, H.; He, L.; Cheng, J. Study on the construction and application of 3D visualization platform for the Yellow River Basin. In Frontiers of WWW Research and Development. Lecture Notes in Computer Science, 3841; Zhou, X., Li, J., Shen, H.T., Kitsuregawa, M., Zhang, Y., Eds.; Springer: Berlin/Heidelberg, Germany, 2006.

65. Yong, T.; Zheng, Y.; Zheng, C. Development of a visualization tool for integrated surface water-groundwater modeling. Comput. Geosci. 2016, 86, 1-14.

66. Mackay, E.B.; Wilkinson, M.E.; Macleod, C.J.A.; Beven, K.; Percy, B.J.; Macklin, M.G.; Quinn, P.F.; Stutter, M.; Haygarth, P.M. Digital catchment observatories: A platform for engagement and knowledge exchange between catchment scientists, policy makers, and local communities. Water Resour. Res. 2015, 51, 4815-4822. [CrossRef]

67. Medema, W.; Furber, A.; Adamowski, A.; Zhou, Q.; Mayer, I. Exploring the potential impact of serious games on social learning and stakeholder collaborations for transboundary watershed management of the St. Lawrence River Basin. Water 2016, 8, 175. [CrossRef] 
68. Farjad, B.; Pooyandeh, M.; Gupta, A.; Motamedi, M.; Marceau, D. Modelling interactions between land use, climate, and hydrology along with stakeholders' negotiation for water resources management. Sustainability 2017, 9, 2022. [CrossRef]

69. Tangible Landscape. Available online: Tangible-landscape.github.io/ (accessed on 10 May 2020).

70. Souffront Alcantara, M.A.; Kesler, C.; Stealey, M.; Nelson, E.J.; Ames, D.P.; Jones, N.L. Cyberinfrastructure and web Apps for managing and disseminating the National Water Model. J. Am. Water Resour. Assoc. 2017. [CrossRef]

71. Grigg, N.S. Water governance: From ideals to effective strategies. Water Int. 2011, 36, 799-811. [CrossRef]

72. Blodgett, D.L.; Read, E.K.; Lucido, J.M.; Slawecki, T.; Young, D. An analysis of water data systems to inform the Open Water Data Initiative. J. Am. Water Resour. Assoc. 2016, 52, 845-858. [CrossRef]

73. Lember, V.; Brandsen, T.; Tõnurist, P. The potential impacts of digital technologies on co-production and co-creation. Public Manag. Rev. 2019, 21, 1665-1686. [CrossRef]

74. Casiano Flores, C.; Crompvoets, J. Assessing the governance context support for creating a pluvial flood risk map with climate change scenarios: The Flemish subnational case. ISPRS Int. J. Geo Inf. 2020, 9, 460. [CrossRef]

(C) 2020 by the authors. Licensee MDPI, Basel, Switzerland. This article is an open access article distributed under the terms and conditions of the Creative Commons Attribution (CC BY) license (http://creativecommons.org/licenses/by/4.0/). 